\title{
OPTIMASI PROSES PEMBUATAN MI SORGUM DENGAN MENGGUNAKAN EKSTRUDER ULIR GANDA \\ (Optimization of Sorghum Noodle Processing with Twin Screw Extruder)
}

\author{
Tjahja Muhandri, Subarna, Ivan Mustakim \\ Departemen IImu dan Teknologi Pangan, FATETA - IPB \\ Kampus IPB Darmaga, PO BOX 220, Darmaga, Bogor \\ cahyomuhandri@yahoo.com
}

Diterima 29 April 2013/ Disetujui 13 Mei 2013

\begin{abstract}
The objective of this research was to optimize the sorghum noodle processing with two variables i.e. extruder temperature $\left(80,85,90^{\circ} \mathrm{C}\right)$ and screw speed $(10,15,20 \mathrm{~Hz})$. The optimum process was chosen by using Response Surface Methodology (RSM), based on 2 parameters, i.e. cooking loss and elongation. The result of this research showed that the optimum processing condition with desirability of 0.736, was resulted from the combination of the extruder temperature of $85^{\circ} \mathrm{C}$ and screw speed of $20 \mathrm{~Hz}$. The verification showed that the sorghum noodles from this optimum condition had cooking loss of $11.87 \%$, and elongation of 234.84 .
\end{abstract}

Keywords: noodle, sorghum, optimization, twin screw extruder, RSM

\section{PENDAHULUAN}

Salah satu kebijakan pembangunan pangan dalam mencapai ketahanan pangan adalah dengan diversifikasi pangan. Program diversifikasi pangan berbasis pangan lokal bertujuan mengurangi ketergantungan sumber pangan pada gandum yang masih tinggi. Salah satu komoditas lokal yang potensial dikembangkan menjadi produk pangan alternatif adalah sorgum.

Sorgum memiliki beberapa keunggulan antara lain dapat bertahan pada kondisi kering (Suprapto dan Mudjisihono 1987), umur tanam yang pendek (100-110 hari), daya adaptasi terhadap lahan yang tinggi, dan biaya produksi yang rendah (Suarni, 2004). Selain itu, sorgum tahan terhadap hama burung karena mengandung tanin. Sorgum mengandung senyawa-senyawa polifenol yang memilki daya antioksidan sangat besar, lebih besar dari vitamin E dan vitamin $\mathrm{C}$ yang selama ini dikenal sebagai antioksidan alami (Awika dan Rooney, 2004). Biji sorgum dapat dimanfaatkan sebagai pangan, pakan, maupun bahan baku industri, sedangkan daunnya digunakan untuk pakan ternak.

Mi merupakan jenis makanan yang disukai konsumen Indonesia. Namun konsumsi mi ini dapat menurunkan devisa negara, mengingat mi merupakan produk yang dibuat dari tepung terigu, suatu komoditas impor. Berdasarkan data BPS tahun 2011 impor gandum sebesar 5.486.745 ton. Tingginya angka impor gandum menyebabkan pengurangan devisa negara dan ketergantungan terhadap impor gandum yang nantinya dibuat tepung terigu. Oleh sebab itu perlu adanya pengembangan teknologi mi berbahan baku selain tepung terigu, yaitu dengan memanfaatkan tepung sorgum. Dengan demikian mi sorgum kering ini diharapkan dapat mengurangi ketergantungan masyarakat terhadap produk-produk mi berbasis terigu sekaligus meningkatkan ketahanan pangan.

Penelitian tentang mi sorgum telah dilakukan sebelumnya oleh Suhendro et al. (2000) dan Wonojatun (2012) namun dilakukan menggunakan ekstruder ulir tunggal pada skala labaoratorium dengan kapasitas 1-2 $\mathrm{kg}$ per jam. Penelitian ini ditujukan untuk optimasi proses pembuatan mi sorgum kering dengan metode ekstrusi menggunakan ekstruder ulir ganda yang memiliki kapasitas cukup besar yaitu 40-50 kg per jam. Optimasi dilakukan dengan perlakuan suhu dan kecepatan ulir. Dengan dua ulir yang bekerja, shear akan lebih merata dan lebih tinggi. Oleh karena itu, setiap partikel bahan akan diproses dengan lebih konsisten sehingga diperoleh struktur dan tekstur yang lebih homogen. Ekstruder ulir ganda memiliki fleksibilitas yang lebih baik dibandingkan dengan ekstruder ulir tunggal (Muchtadi et al. 1987). 


\section{Bahan dan Alat}

\section{METODOLOGI}

Bahan-bahan yang digunakan dalam penelitian ini terdiri dari sorgum varietas Numbu yang diperoleh dari BIOTROP (Bogor), $\mathrm{NaCl}$, dan air. Bahan-bahan lainnya yang digunakan yaitu bahan-bahan kimia untuk analisis proksimat.

Alat yang digunakan dalam penelitian ini terdiri dari ekstruder ulir ganda (Berto Industries), vibrating screen, pin disc mill, alat penyosoh satake grain mill, alat bantu (mixer, sendok pengaduk, baskom). Peralatan lainnya yang digunakan yaitu peralatan untuk analisis fisik berupa Texture Analyzer Stable Micro System TAXT2i, chromameter CR300 Minolta.

\section{Rancangan Percobaan}

Rancangan percobaan yang digunakan yaitu respon permukaan historical data. Historical data merupakan salah satu rancangan untuk mendapatkan hasil proses yang optimal dengan cara memasukkan hasil trial berupa kombinasi variabel proses dan respon ke dalam program design expert 7.0 yang kemudian akan dianalisis lebih lanjut. Variabel proses dalam penelitian ini terdiri dari suhu dan kecepatan ulir. Kisaran suhu yang digunakan adalah $80-90^{\circ} \mathrm{C}$ sedangkan kisaran kecepatan ulir adalah 10-20 Hz. Penentuan kisaran tersebut berdasarkan pembuatan beras analog yang menggunakan suhu $85^{\circ} \mathrm{C}$ dan kecepatan $15 \mathrm{~Hz}$. Kemudian suhu dan kecepatan tersebut menjadi titik tengah pada penelitian ini. Sehingga ditetapkan suhu minimal $80^{\circ} \mathrm{C}$ dan suhu maksimal $90^{\circ} \mathrm{C}$, kecepatan ulir minimal $10 \mathrm{~Hz}$ dan kecepatan ulir maksimal $20 \mathrm{~Hz}$. Setelah variabel dan kisaran tiap variabel ditentukan maka dihasilkan kombinasi-kombinasi kondisi proses. Proses yang dilakukan terdiri dari 18 proses kombinasi suhu dan kecepatan (Tabel 1.).

Tabel 1. Rancangan proses pembuatan mi sorgum

\begin{tabular}{|c|c|c|c|c|c|}
\hline Formula & $\begin{array}{l}\text { Suhu } \\
\left({ }^{\circ} \mathrm{C}\right)\end{array}$ & $\begin{array}{c}\text { Kecepatan } \\
(\mathrm{Hz})\end{array}$ & Formula & $\begin{array}{l}\text { Suhu } \\
\left({ }^{\circ} \mathrm{C}\right)\end{array}$ & $\begin{array}{c}\text { Kecepatan } \\
(\mathrm{Hz})\end{array}$ \\
\hline 1 & 80 & $10 \mathrm{~A}$ & 10 & 85 & $15 \mathrm{~B}$ \\
\hline 2 & 80 & $10 \mathrm{~B}$ & 11 & 85 & $20 \mathrm{~A}$ \\
\hline 3 & 80 & $15 A$ & 12 & 85 & $20 \mathrm{~B}$ \\
\hline 4 & 80 & 15B & 13 & 90 & $10 \mathrm{~A}$ \\
\hline 5 & 80 & $20 \mathrm{~A}$ & 14 & 90 & $10 \mathrm{~B}$ \\
\hline 6 & 80 & 20B & 15 & 90 & $15 A$ \\
\hline 7 & 85 & $10 \mathrm{~A}$ & 16 & 90 & 15B \\
\hline 8 & 85 & $10 \mathrm{~B}$ & 17 & 90 & $20 \mathrm{~A}$ \\
\hline 9 & 85 & $15 A$ & 18 & 90 & $20 \mathrm{~B}$ \\
\hline
\end{tabular}

Parameter atau respon yang diukur terdiri dari cooking loss dan elongasi. Analisis respon menggunakan piranti lunak design expert 7.0 memberikan suatu model polinomial yang mewakili respon tiap parameter. Model polinomial terdiri dari model rata-rata, linear, kuadratik, dan kubik. Model tersebut ditampilkan dalam bentuk plot kontur atau tiga dimensi. Model dari masing-masing respon yang diperoleh selanjutnya dioptimasi. Proses optimasi dipilih dengan desirability tertinggi berdasarkan penetapan target respon cooking loss adalah minimum, target elongasi, suhu ekstruder dan kecepatan ulir adalah in range. Tahap selanjutnya adalah verifikasi, untuk membuktikan kesesuaian nilai respon aktual dengan nilai respon prediksi.

\section{Pembuatan Mi Sorgum Kering}

Pembuatan mi sorgum dilakukan dengan mencampurkan bahan yaitu garam $2 \%$, air $55 \%$, dan tepung sorgum 100\% menggunakan mixer selama 5 menit. Kemudian, adonan dimasukkan ke dalam ekstruder dengan variabel suhu dan kecepatan ulir yang telah ditentukan. Untaian mi yang keluar sepanjang 1.5 meter pertama dibuang dan tidak digunakan dengan asumsi bahwa kondisi proses belum stabil. Untaian mi selanjutnya diambil untuk analisis lalu dipisahkan antar helai dan dicetak sesuai dengan berat yang diinginkan. Mi basah yang sudah dicetak kemudian dikeringkan dengan kipas angin selama semalam.

\section{Analisis Fisik}

Analisis fisik yang dilakukan terdiri dari (1) analisis cooking loss (2) analisis elongasi dan profil tekstur dengan Texture Analyzer (3) Analisis warna dengan chromamometer (Hutching 1999) serta analisis daya serap air metode sentrifugasi (Modifikasi Anderson 1969 dalam Ganjyal 2006). 


\section{Analisis Kimia}

Analisis kimia berupa analisis kadar air metode oven (SNI 01-2891-1992), analisis kadar abu (SNI 012891-1992), analisis kadar protein (AOAC 960.52), analisis kadar lemak (SNI 01-2891-1992), analisis kadar karbohidrat (Nielsen 2010), analisis kadar pati (sakarosa) metode Luff Schoorl dengan modifikasi (Sudarmadji et al. 1997), dan analisis kadar amilosa dan amilopektin (Apriyantono et al. 1989).

\section{HASIL DAN PEMBAHASAN}

\section{Hasil analisis proksimat tepung sorgum numbu}

Hasil analisis menunjukkan bahwa tepung sorgum numbu memiliki kadar air $13.52 \% \mathrm{bb}$, kadar protein $8.50 \%$ bk, kadar lemak sebesar $2.42 \%$ bk, kadar abu $0.84 \%$ bk, kadar karbohidrat $88.23 \%$ bk, kadar pati 82.18 $\%$ bk, dan kandungan amilosa sebesar 22,46\%. Menurut Guo et al. (2003) pada umumnya mi di Asia dibuat dari tepung dengan kandungan amilosa $1-29 \%$, namun kandungan amilosa optimum yang memberikan kualitas mi terbaik yaitu $21-24 \%$. Berdasarkan hal tersebut, kadar amilosa pada tepung sorgum numbu masih cukup baik untuk diolah menjadi produk mi ekstrusi.

\section{Daya Serap Air}

Penambahan sebanyak 55\% air untuk adonan mi sorgum menunjukkan bahwa sorgum membutuhkan lebih sedikit air untuk menghasilkan adonan yang memiliki fisik dan tingkat konsistensi yang sama dengan adonan mi jagung (Muhandri, 2012). Hal ini dibuktikan dengan adanya analisis daya serap air terhadap tepung jagung dan tepung sorgum yang dapat dilihat pada Tabel 2.

Menurut Gomez dan Aguilera (1983), nilai daya serap air tergantung pada ketersediaan grup hidrofilik dan kapasitas pembentukan gel dari makromolekul pati, yaitu pati tergelatinisasi dan terdekstrinisasi. Semakin banyak yang tergelatinisasi dan terdekstrinisasi, semakin besar kemampuan produk menyerap air.

Elliason (1981) menyatakan bahwa granula pati dapat basah dan secara spontan dapat terdispersi dalam air atau minyak. Hal ini menunjukkan bahwa granula dapat memberikan gugus hidrofilik atau hidrofobik. Daya serap air yang besar pada tepung jagung menunjukkan bahwa jagung memiliki grup hidrofilik yang lebih banyak dibandingkan tepung sorgum.

Tabel 2. Daya serap air pada tepung jagung dan tepung sorgum

\begin{tabular}{cc}
\hline Sampel & Daya serap air (\%) \\
\hline Tepung sorgum 100 mesh & 94.35 \\
Tepung jagung 100 mesh & 118.92 \\
\hline
\end{tabular}

\section{Cooking Loss}

Semua model prediksi untuk respon cooking loss tidak signifikan karena $R$ squared model terlalu rendah (di bawah 0.75 ). Model yang memiliki $\mathrm{R}$ squared tertinggi adalah Model Cubic dengan nilai sebesar 0.452 yang menunjukkan bahwa model tersebut tidak cukup baik digunakan untuk memprediksi nilai cooking loss.

Meskipun demikian, berdasarkan Gambar 1, terlihat bahwa cooking loss dipengaruhi oleh suhu ekstruder. Cooking loss menurun dengan peningkatan suhu dari $80^{\circ} \mathrm{C}$ ke $85^{\circ} \mathrm{C}$ yaitu dari $13.67 \%$ menjadi $11.94 \%$. Hal ini sejalan dengan pernyataan Charutigon et al. (2007) bahwa peningkatan suhu ekstruder dapat menurunkan cooking loss mi beras.

Menurut Charutigon et al. (2007), tingkat cooking loss tergantung pada tingkat gelatinisasi dan kekuatan struktur gel mi. Pada mi berbasis pati, cooking loss disebabkan oleh kelarutan pati tergelatinisasi yang ikatannya lemah di permukaan mi. Dengan meningkatnya suhu, maka ikatan gel menjadi semakin kuat sehingga cooking loss menjadi kecil.

Pada penelitian ini peningkatan suhu dari $85^{\circ} \mathrm{C}$ ke $90^{\circ} \mathrm{C}$ meningkatkan cooking loss yaitu dari $11.94 \%$ menjadi $14.41 \%$. Hal ini diduga karena ikatan antar pati tergelatinisasi dan struktur gel melemah sehingga pati banyak terlepas dan menyebabkan cooking loss menjadi lebih besar.

Cooking loss mi sorgum lebih tinggi (11.93\%) dibandingkan cooking loss spaghetti komersial $(6.72 \%)$. Namun cooking loss mi sorgum ini masih berada pada rentang cooking loss mi komersial (Charutigon et al. 2007) yaitu antara $7,5-12,5 \%$. Bentuk permukaan dari hubungan interaksi antar komponen dapat dilihat jelas pada grafik tiga dimensi yang ditunjukkan pada Gambar 1. 


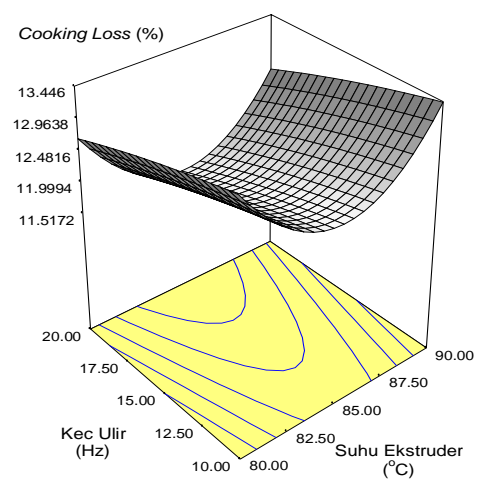

Gambar 1. Grafik hubungan cooking loss dengan suhu dan kecepatan ulir

\section{Elongasi}

Elongasi memiliki bentuk model Cubic. $R$ squared model dari elongasi sebesar 0.9194 yang menunjukkan bahwa model tersebut cukup baik digunakan untuk memprediksi nilai elongasi. Persamaan untuk respon elongasi adalah:

\section{Elongasi $=230.16+36.26 \mathrm{~A}-62.43 \mathrm{~A}^{2}-48.44 \mathrm{AB}^{2}$}

Dimana : $A=$ Suhu ekstruder $B=$ Kecepatan ulir

Berdasarkan persamaan polinomial tersebut, dapat dilihat bahwa nilai elongasi dipengaruhi oleh suhu ekstruder dan interaksi antara suhu dengan kecepatan ulir. Elongasi meningkat dengan peningkatan suhu dari $80^{\circ} \mathrm{C}$ ke suhu $85^{\circ} \mathrm{C}$ yaitu dari $162.06 \%$ menjadi $227.74 \%$. Hal ini seperti penelitian yang dilakukan oleh Muhandri (2012) mengenai pembuatan mi jagung dengan ekstruder ulir tunggal yang menunjukkan bahwa peningkatan suhu ekstruder dapat meningkatkan elongasi mi jagung.

Menurut Muhandri (2012) suhu semakin tinggi menyebabkan gelatinisasi semakin tinggi. Gelatinisasi yang tinggi pada adonan selama proses ekstrusi menyebabkan kekuatan struktur gel semakin tinggi sehingga mi semakin tinggi elongasinya. Namun, elongasi menurun dengan peningkatan suhu dari $85^{\circ} \mathrm{C}$ ke $90^{\circ} \mathrm{C}$ yaitu dari $227.74 \%$ menjadi $161.41 \%$. Penurunan elongasi diduga pada kisaran suhu $85^{\circ} \mathrm{C}$ ke $90^{\circ} \mathrm{C}$ suhu terlalu tinggi yang menyebabkan tekstur mi rusak sehingga elongasi menurun.

Elongasi mi sorgum (227.52\%) nilainya sudah mendekati elongasi spaghetti komersial (237\%). Oleh karena itu, elongasi mi sorgum sudah cukup baik. Bentuk permukaan dari hubungan interaksi antar komponen dapat dilihat jelas pada grafik tiga dimensi yang ditunjukkan pada Gambar 2.

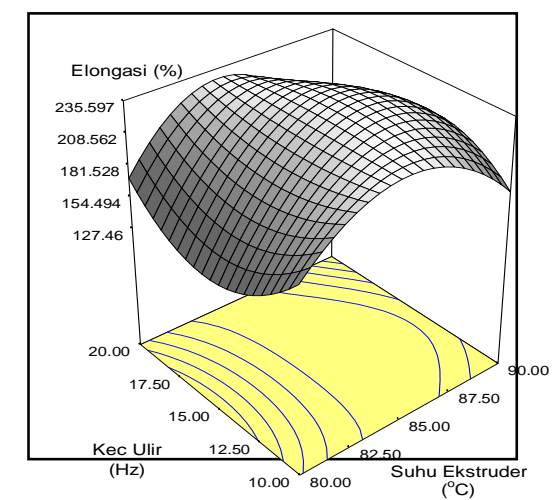

Gambar 2. Grafik hubungan elongasi dengan suhu dan kecepatan ulir 


\section{Penentuan Proses Optimum}

Pemilihan parameter proses yang optimum dilakukan dengan mempertimbangkan aspek proses (suhu dan kecepatan ulir ekstruder) dan karakteristik produk mi sorgum (elongasi dan cooking loss). Kriteria proses optimum disajikan pada Tabel 3. Ilustrasi grafik tiga dimensi untuk menunjukkan nilai desirability disajikan pada Gambar 3.

Tabel 3. Kriteria optimasi proses untuk tiap faktor dan respon

\begin{tabular}{|c|c|c|c|c|}
\hline Nama komponen/respon & Goal & Batas bawah & Batas atas & Importance* \\
\hline Suhu & In range & 80 & 90 & $3(+++)$ \\
\hline Kecepatan ulir & In range & 10 & 20 & $3(+++)$ \\
\hline Cooking loss & Minimum & 9.72 & 15.86 & $3(+++)$ \\
\hline Elongasi & In range & 108.34 & 269.75 & $3(+++)$ \\
\hline
\end{tabular}

Keterangan: * rentang nilai dari 1-5, semakin besar nilainya semakin diutamakan untuk dioptimasi

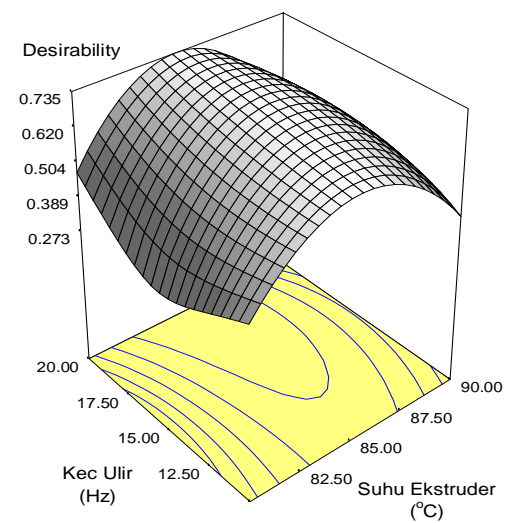

Gambar 3. Grafik optimasi proses berdasarkan nilai Desirability

Optimasi proses menghasilkan proses terpilih (selected) berdasarkan hasil analisis dan solusi dari design expert 7.0. Proses optimum pembuatan mi sorgum adalah pada suhu $85^{\circ} \mathrm{C}$ dan kecepatan $20 \mathrm{~Hz}$. Proses optimum memiliki nilai desirability sebesar 0.736 . Proses optimum tepilih ini diprediksikan akan memiliki nilai cooking loss sebesar $11.53 \%$, elongasi sebesar $226.88 \%$. Foto mi kering sorgum dan mi sorgum yang telah direhidrasi disajikan pada Gambar 4.

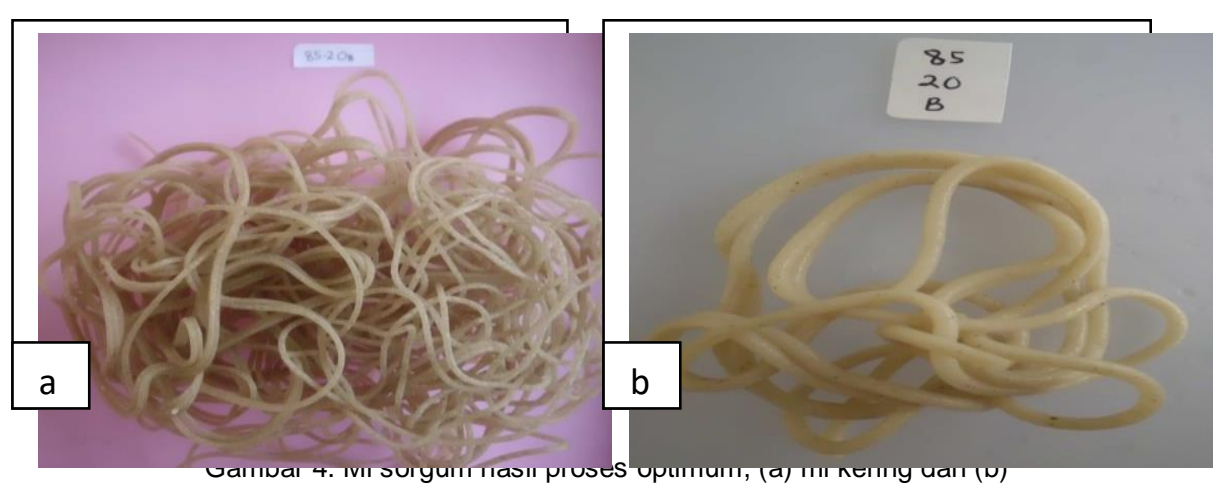

mi setelah direhidrasi

Tjahja Muhandri, Subarna, Ivan Mustakim 


\section{Verifikasi Karakteristik Mi pada Proses Optimum}

Verifikasi dilakukan untuk memperoleh keyakinan bahwa karakteristik mi hasil prediksi menggunakan design expert proses optimum, sesuai dengan karakteristik mi ketika diujicoba produksinya pada kondisi optimum tersebut. Mi dibuat pada kondisi proses suhu $85^{\circ} \mathrm{C}$ dan kecepatan ulir $20 \mathrm{~Hz}$, kemudian dibandingkan dengan karakteristik hasi prediksi. Perbandingan karakteristik mi sorgum hasil prediksi dan hasil verifikasi disajikan pada Tabel 4.

Tabel 4. Karakteristik mi hasil prediksi dan hasil verifikasi pada kondisi optimum proses

\begin{tabular}{|c|c|c|c|c|c|}
\hline \multirow{2}{*}{ Respons } & \multirow{2}{*}{ Prediksi } & \multirow{2}{*}{$\begin{array}{c}\text { Hasil } \\
\text { Verifikasi }\end{array}$} & \multirow{2}{*}{$\begin{array}{c}\text { SE } \\
\text { Mean }\end{array}$} & \multicolumn{2}{|c|}{$95 \% \mathrm{Cl}$} \\
\hline & & & & Low & High \\
\hline Cooking loss & 11.53 & 11.87 & 0.56 & 10.73 & 13.12 \\
\hline Elongasi & 226.88 & 234.84 & 12.62 & 200.62 & 254.42 \\
\hline
\end{tabular}

Berdasarkan verifikasi yang dilakukan (Tabel 4) dapat diketahui bahwa data hasil verifikasi masih sesuai dengan prediksi yang telah dibuat oleh program design expert 7.0. Hal ini ditunjukkan oleh respon tekstur cooking loss dan elongasi memenuhi $95 \%$ confident interval yang telah diprediksikan oleh program design expert 7.0.

\section{Komposisi Kimia dan Warna Mi Sorgum}

Hasil analisis proksimat mi sorgum proses optimum dapat dilihat pada Tabel 5. Kadar air produk mi hasil proses optimum sebesar $11.74 \%$ bb, kadar protein sebesar $5.11 \%$ bb, kadar abu sebesar $2.23 \%$ (bb), dan kadar lemak sebesar $0.18 \%(\mathrm{bb})$. Kandungan tertinggi pada produk mi hasil penelitian ini adalah karbohidrat sebesar $80.75 \%(\mathrm{bb})$.

Tabel 5. Hasil analisis proksimat mi sorgum hasil proses optimum

\begin{tabular}{lll}
\hline \multicolumn{1}{c}{ Komponen } & Basis basah & Basis kering \\
\hline Air (\%) & 11.74 & 13.31 \\
Abu (\%) & 2.23 & 2.64 \\
Protein (\%) & 5.11 & 6.06 \\
Lemak (\%) & 0.18 & 0.21 \\
Karbohidrat (\%) & 80.75 & 91.49 \\
\hline
\end{tabular}

Berdasarkan analisis warna metode Hunter dengan menggunakan chromameter mi sorgum dari hasil proses optimum pada suhu $85^{\circ} \mathrm{C}$ dan kecepatan $10 \mathrm{~Hz}$ mempunyai nilai $\mathrm{L}$ (61.17), a (1.35), b(10,39), dan ${ }^{\circ} \mathrm{Hue}$ $(82,62)$. Hasil pengukuran warna menunjukkan warna mi sorgum adalah putih kekuningan.

\section{SIMPULAN}

Proses optimum pembuatan mi sorgum menggunakan ekstruder ulir ganda adalah suhu $85^{\circ} \mathrm{C}$ dan kecepatan $20 \mathrm{~Hz}$. Proses optimum tersebut mempunyai nilai desirability 0,736 . Mi sorgum yang dihasilkan dari proses optimum memiliki cooking loss $11.87 \%$ dan elongasi $234.84 \%$.

Hasil analisis proksimat mi sorgum kering menunjukkan bahwa mi sorgum kering hasil proses optimum mempunyai kadar air sebesar $11.74 \%$, kadar abu $2.23 \%$, kadar protein $5.11 \%$, dan kadar karbohidrat (by difference) $80.75 \%$. Berdasarkan analisis warna metode Hunter dengan menggunakan chromameter mi sorgum dari hasil proses optimum pada suhu $85^{\circ} \mathrm{C}$ dan kecepatan $20 \mathrm{~Hz}$ mempunyai warna putih kekuningan dengan nilai $L$ (61.17), a (1.35), b(10,39), dan ${ }^{\circ}$ Hue $(82,62)$.

\section{DAFTAR PUSTAKA}

[AOAC]. 1995. Official Method of Analysis 960.5, Chapter 12.1.07, hal 7.

Apriyantono A, Fardiaz D, Puspitasari NL, Sedarwati, Budijanto S. 1989. Analisis Pangan. IPB Press, Bogor.

Awika JM, Rooney LW. 2004. Sorghum phytochemicals and their potential impact on human health. J. Science Phytochemistry 65:1199-1221.

Charutigon C, Jintana J, Pimjai N, Vilai R. 2007. Effects of processing conditions and the use of modified starch and monoglyseride on some properties of extruded rice vermicelli. Swiss Society of F Sci Tech 41 : $642-651$. 
Elliason AC.1981. Effect of water content on the gelatinization of wheat starch. Starke 32:270-272.

Ganjyal M, Hanna MA, Supprung M, Noom H, Jones D. 2006. Modeling selected properties of extruded rice flour and rice starch by neutral network and statistics. J Cereal Chem 83:223-227.

Gomez, M.H. and J.M. Aguilera. 1983. Changes in the starch fraction during extrusion - cooking of corn. J Food Sci. 48: 378 .

Guo G, DS Jackson, RA Graybosch, and AM Parkhurst. 2003. Asian salted noode quality: Impact of Amylose content adjustments using waxy wheat flour. J cereal Chem 80:437-445.

Hutching JB. 1999. Food Colour and Appearance. $2^{\text {nd }}$ ed. Gatersburg: Aspen Publishing Inc.

Muchtadi, T.R., P. Hariyadi, dan A.B. Ahza. 1987. Teknologi Pemasakan Ekstrusi. Pusat Antar Universitas Pangan dan Gizi, Institut Pertanian Bogor.

Muhandri T. 2012. Karakteristik Reologi Mi Jagung dengan Ekstrusi Pemasak Pencetak [disertasi]. Bogor: Institut Pertanian Bogor.

Nielsen SS. 2010. Food Analysis. $4^{\text {th }}$ ed. USA:Springer.

Suarni. 2004. Pemanfaatan tepung sorgum untuk produk olahan. J. Litbang Pertanian 23 (4).

Sudarmadji S, Haryono B, dan Suhardi. 1997. Prosedur Analisa untuk Bahan Makanan dan Pertanian Edisi Keempat. Liberty, Yogyakarta.

Suhendro EL, Kunetz CF, Mc Donough CM, Rooney LW, Waniska RD. 2000. Cooking characteristic and quality of noodles from food sorghum. [Abstract]. Cereal Chemistry 77, 96-100.

Suprapto HS dan Mudjisihono RS. 1987. 1987. Budidaya dan Pengolahan Sorgum. Jakarta: Penebar Swadaya. Wonojatun. 2010. Formulasi dan Analisis Nilai Gizi Produk Mi Berbasis Sorgum. [skripsi]. Bogor: Institut Pertanian Bogor. 